\title{
Efek anti radang ekstrak torbangun (Coleus amboinicus) pada in- duksi cisplatin tikus putih wistar
}

\author{
Rondius Solfaine $^{1 *}$, Iwan Sahrial Hamid ${ }^{2}$ \\ ${ }^{1}$ Laboratorium Patologi, Fakultas Kedokteran Hewan, Universitas Wijaya Kusuma, Surabaya, Indonesia \\ ${ }^{2}$ Departemen Kedokteran Dasar, Fakultas Kedokteran Hewan, Universitas Airlangga, Surabaya, Indonesia
}

\begin{abstract}
ABSTRAK: Penelitian ini bertujuan menganalisis aktivitas ekstrak torbangun (Coleus amboinicus) terhadap biokimia darah dan gambaran histopatologi ginjal pada induksi cisplatin pada tikus putih Wistar (Rattus norvegicus). Penelitian ini menggunakan 24 tikus putih galur Wistar yang terbagi menjadi 3 kelompok yaitu kelompok kontrol negatif dengan pemberian plasebo (P0), kelompok kontrol positif berupa induksi cisplatin dengan pemberian CMC-Na $0.1 \%(\mathrm{P} 1)$, dan kelompok induksi cisplatin dengan pemberian ekstrak torbangun $500 \mathrm{mg} / \mathrm{kg}$ bb (P2). Pembuatan nefropati pada kelompok perlakuan dengan injeksi intra peritoneal hari ke-4 dosis tunggal cisplatin $5 \mathrm{mg} / \mathrm{kg}$ bb. Seluruh kelompok tikus dikorbankan dan diambil sampel darah untuk diukur kadar blood urea nitrogen (BUN), serum kreatinin (SK) dan alkalin phospatase (ALP) sebagai tes fungsi ginjal. Sampel organ fiksasi dengan BNF $10 \%$ untuk histopatologi. Hasil menunjukkan bahwa pemberian ekstrak Coleus amboinicus menurunkan konsentrasi BUN, serum kreatinin, dan alkalin phospatase pada kelompok dengan ekstrak torbangun (P2) dibandingkan dengan kelompok kontrol positif $(\mathrm{p}<0,05)$. Analisis histopatologi terlihat perdarahan multifokal, infiltrasi interstisial, adanya adesi membrane capsula glomerulus dan nekrotik tubular secara difus pada kelompok kontrol positif dengan induksi cisplatin (P1). Kerusakan pada glomerulus dan tubulus ginjal lebih ringan pada kelompok yang diberi eksrak torbangun (P2). Berdasarkan hasil penelitian dapat disimpulkan pemberian ekstrak torbangun dapat menormalkan gambaran biokimia darah dan menghambat kerusakan ginjal dengan cara menghambat keradangan pada induksi cisplatin pada tikus putih.
\end{abstract}

\section{Kata kunci:}

Coleus amboinicus, cisplatin, wistar, biokimia darah

\section{- PENDAHULUAN}

Nefropati merupakan gagal ginjal akut ditandai dengan lesi glomerulosklerosis, penebalan membran basal glomerulus, proliferasi sel mesangial, penurunan laju filtrasi glomerulus, albuminuria, tekanan darah tinggi dan retensi cairan (Balakumar et al. 2008). Cisplatin adalah agen kemoterapi, yang memiliki efek samping merusak ginjal (Roncal et al. 2007). Anti Inflamasi Non steroid (AINS) merupakan obat yang digunakan untuk peradangan nefropati. Obat AINS bekerja menghambat enzim cyclooxygenase (COX) yang merubah asam arakhidonat menjadi prostaglandin. Namun, obat AINS diketahui menyebakan gangguan ginjal, hepatotoksik dan alergi (Murtaza et al. 2017).

Torbangun (Coleus amboinicus) telah digunakan sebagai tanaman obat tradisional. Pemberian ekstrak daun torbangun dapat meningkatkan ekskresi kalsium oksalat dan protein lainnya. Uji toksisitas akut pada mencit tidak menimbulkan kematian, paralisis, oedema, gangguan respirasi, gangguan fisik dan tidak menimbulkan perubahan histopatologis pada organ (Pillai et al. 2011). Penelitian ini bertujuan menganalisis aktivitas ekstrak torbangun (Coleus amboinicus) terhadap parameter biokimia darah dan gambaran histopatologi ginjal pada induksi cisplatin pada tikus putih Wistar (Rattus norvegicus)

\section{- METODE PENELITIAN}

Hewan uji yang digunakan adalah tikus putih (Rattus norvegicus) jantan galur Wistar sebanyak 24 ekor umur 2-3 bulan dan berat badan 150-200 gram. Hewan coba dibagi dalam 3 kelompok; kontrol negatif ( $\mathrm{P} 0)$ dengan plasebo, kontrol positif (P1) diberikan suspensi CMC Na $0.1 \%$, dan kelompok perlakuan (P2) diberikan ekstrak daun torbangun secara peroral dengan dosis $500 \mathrm{mg} / \mathrm{kg}$ bb setiap hari selama 7 hari. Induksi cisplatin $5 \mathrm{mg} / \mathrm{kg}$ bb secara intraperitoneal. Seluruh tikus dikorbankan pada hari ke-8 dan diambil sampel organ ginjal dengan fiksasi buffer neutral formalin $10 \%$ untuk analisis histopatologi. Sampel darah diambil untuk tes fungsi ginjal kadar BUN, serum kreatinin dan alkalin phospatase dengan metode kolorimetri. Data yang diperoleh diuji dengan One Way ANOVA dan dilanjutkan dengan Post Hoc Test Duncan Multiple Range Test. Hasil pengamatan histopatologi dianalis secara deskriptif untuk mengetahui beda nyata antar kelompok. 


\section{- HASIL DAN PEMBAHASAN}

Berdasarkan hasil penelitian, rata-rata blood urea nitrogen (BUN) pada tikus kontrol berkisar antara 51,83 mg/dL. Kelompok P1 secara signifikan meningkatkan kadar BUN sebesar 263,97 mg/dl yang lebih tinggi dibandingkan dengan kelompok P2 sebesar 129,03 mg/dl $(\mathrm{p}<0,05)$. Kadar kreatinin dalam tikus kontrol (P0) adalah 0,68 mg/dl. Kadar kreatinin di kelompok P1 menunjukkan peningkatan rata-rata $3,29 \mathrm{mg} / \mathrm{dl}$, yang merupakan peningkatan yang signifikan jika dibandingkan dengan kelompok P2 sebesar 1,93 mg/dl kontrol memilki rataaan sebesar 185,6 mg/dL. Kadar ALP kelompok induksi (P1) cisplatin dengan rerata $532,38 \mathrm{mg} / \mathrm{dL}$ memiliki perbedaan signifikan dengan kelompok ekstrak torbangun sebesar 274,46 mg /dL. Hasil induksi dengan pemberian cisplatin pada kelompok perlakuan P1 dan P2 menunjukkan seluruh kelompok perlakuan mengalami gangguan fungsi ginjal. Menurut Mazzali et al. (2005), nefropati ditandai dengan tingkat BUN yang tinggi akibat hipovolemia dan dehidrasi pada tubulus ginjal.

Tabel 1 Parameter fungsi ginjal pada kelompok perlakuan

\begin{tabular}{|c|c|c|c|}
\hline Kelompok & $\begin{array}{c}\text { BUN } \\
(\mathrm{mg} / \mathrm{dL})\end{array}$ & $\begin{array}{c}\text { Kreatinin } \\
(\mathrm{mg} / \mathrm{dL})\end{array}$ & $\begin{array}{c}\text { Alkaline Phos- } \\
\text { patase (IU/L) }\end{array}$ \\
\hline $\begin{array}{l}\text { Kontrol } \\
\text { (P0) }\end{array}$ & $51,80 \pm 13,00^{\mathrm{a}}$ & $0,68 \pm 0,30^{\mathrm{a}}$ & $185,63 \pm 33,93^{\mathrm{a}}$ \\
\hline $\begin{array}{l}\text { Induksi } \\
\text { cisplatin (P1) }\end{array}$ & $263,97 \pm 32,60^{\mathrm{b}}$ & $3,29 \pm 0,70^{\mathrm{b}}$ & $531,38 \pm 29,64^{\mathrm{b}}$ \\
\hline $\begin{array}{l}\text { Induksi } \\
\text { cisplatin + } \\
\text { ekstrak (P2) }\end{array}$ & $129,03 \pm 32,03^{\mathrm{c}}$ & $1,93 \pm 0,40^{\mathrm{c}}$ & $274,63 \pm 46,99^{c}$ \\
\hline
\end{tabular}

Perubahan histopatologi menunjukkan penurunan fungsi ginjal dibuktikan dengan vakuolisasi degenerasi, inflamasi dan nekrosis tubulus ginjal dan glomerulus (Gambar 1). Hasil penelitian menunjukan bahwa induksi cisplatin $5 \mathrm{mg} / \mathrm{kg}$ bb menyebabkan perubahan pada gambaran histopatologi ginjal. Ditemukan adanya hemoragi, degenerasi, nekrosis dan glomerular infiltration pada kelompok yang diberikan induksi cisplatin $5 \mathrm{mg} / \mathrm{kg}$ bb secara difus. Sementara pada kelompok dengan ekstrak daun torbangun $500 \mathrm{mg} / \mathrm{kg}$ bb mengalami penurunan kerusakan secara menyeluruh pada lesi degenerasi, nekrosis dan inflitrasi glomerular (karioreksis), inti tidak lagi mengambil warna radang pada glomerulus ginjal (Ravindra et al. 2010).

\section{- SIMPULAN}

Pemberian ekstrak torbangun dapat mengembalikan nilai biokimia darah dan menghambat kerusakan ginjal pada induksi cisplatin pada tikus putih.

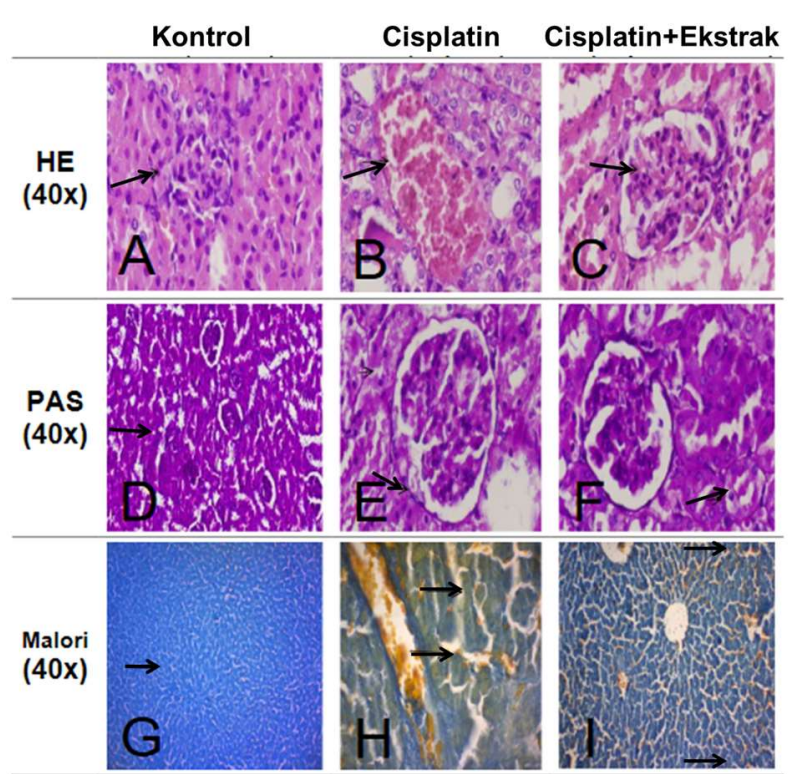

Gambar 1 Histopatologi ginjal tikus menunjukkan sel glomerulus dan tubulus (HE/PAS/Malori, 40x).

\section{- INFORMASI PENULIS}

Penulis Korespondensi

*RS: rondius@uwks.ac.id

Fakultas Kedokteran Hewan Universitas Wijaya Kusuma Surabaya

\section{- UCAPAN TERIMA KASIH}

Penelitian ini didanai oleh Direktorat Riset dan Pengabdian Masyarakat Kementerian Riset, Teknologi dan Pendidikan Tinggi (Kemristekdikti) Kopertis 7 dengan Surat Keputusan nomor 120/SP2H/LT/DRPM/IV/2017.

\section{- PUSTAKA ACUAN}

Balakumar P, Chakkarwar VA, Kumar V, Jain A, Reddy J, Singh M. 2008. Experimental models for nephropathy. Journal of the Renin Angiotensin Aldosterone System. 9(4): 189-195.

Roncal CA, Mu W, Croker B, Reungjui S, Ouyang X, Tabah-fisch I, Johnson RJ, Ejaz AA. 2007. Effect of elevated serum uric acid on cisplatin-induced acute renal failure. American Journal of Physiology-Renal Physiology. 292(1): 116-122.

Pillai PG, Suresh P, Aggarwal G, Doshi G, Bhatia V. 2011. Pharmacognostical standardization and toxicity profile of the methanolic leaf extract of Plectranthus amboinicus (Lour) Spreng. Journal of Applied Pharmaceutical Science. 01(02): 75-81.

Mazzali M, Hughes J, Kim Y, Jefferson JA, Kang D, and Gordon KL. 2001. Elevated Uric Acid Increases Blood Pressure in the Rat by a Novel Crystal-Independent Mechanism. Hypertension. 38: 11011106.

Murtaza S, Shoaib M, Kanwal F, Abbas A, Ashiq S, Shamim S. 2014. Synthesis And Biological Evaluation Of Schiff Bases Of 4Aminophenazone As An Anti-Inflammatory, Analgesic and Antipyretic Agent. Journal Of Saudi Chemical Society. 21: S359S372.

Ravindra P, Bhiwgade DA, Kulkarni S, Rataboli PV, Dhume CY, Sciences L. 2010. Cisplatin induced histological changes in renal tissue of rat. Journal of Cell and Animal Biology. 4(7): 108-111. 